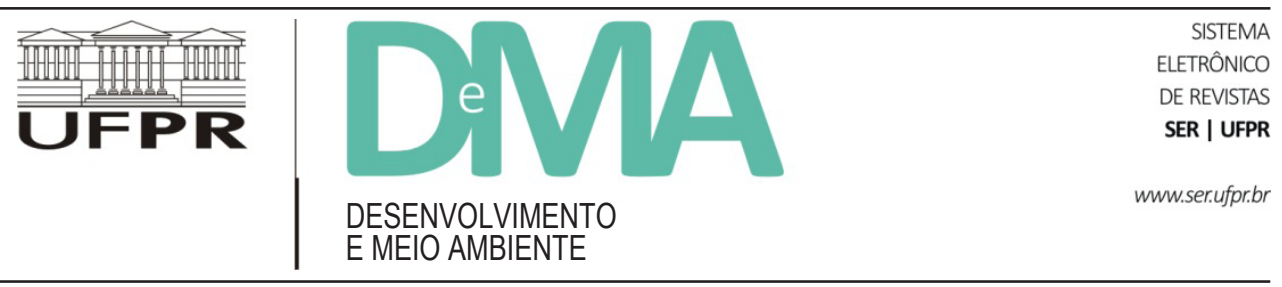

\title{
A Literary Perspective on the Environment: Rethinking Development through Art
}

\section{Uma perspectiva literária sobre o meio ambiente: repensando o desenvolvimento através da arte}

\author{
Davi Silva GONÇALVES ${ }^{1}$ \\ Artigo: Recebido em: 13 de maio de 2013; Versão final aceita em: 12 de março de 2014.
}

${ }^{1}$ Mestre em Letras (UFSC). Doutorando do Programa de Pós-Graduação em Estudos da Tradução (UFSC). E-mail: goncalves.davi@hotmail.com

ABSTRACT Due to the environmental crisis that chokes contemporaneity, it is of paramount importance for society to rethink our physical and abstract behaviours towards nature. Ecocriticism, providing a bridge between literature and nature, allows us to reorganise proven problematic notions, such as progress and development, which tend to gradually separate human beings from the space they occupy. Such separation results in a detachment that hinders our ability to transcend metropolitan, narrow-minded, biased judgments regarding the future of developing countries like Brazil, and perhaps artistic tools like literature are the only ones capable of broadening our reflections for inviting us to go beyond preconditioned perspectives. This article aims at showing how Milton Hatoum's novel The Brothers (2000) implies that we must look for distinct possibilities of developing our spaces, more specifically the Amazon, and, through the analysis of the book as well as the impact of development on the region, the dialogue between literature and nature is proposed. First the theoretical approach on both nature and literature is delineated, followed by a discussion on how important it is to (re)connect subjects and environment, and then by analysing the novel's characters which evince the side effects of "progress" and "growth" in the Amazonian region. The result is a problematisation of normative dichotomies such as savage/ civilised, past/future, subject/space, underdeveloped/developed, and the conclusion that, for development to stop being detrimental to nature, we shall avoid believing in a "faceless environment" (Campbell, 18), that is, one needs to start observing the impact of such development on the lives of those inevitably and automatically marginalised by it.

Keywords: literature; development; environment.

RESUMO Em função do desequilíbrio ecológico que sufoca a contemporaneidade, é fundamental que a sociedade reconsidere sua forma, tanto material quanto abstrata, de lidar com a natureza. A Ecocrítica, ao propor uma ponte entre literatura e natureza, nos permite reorganizar noções que já se mostraram problemáticas, como o progresso ou desenvolvimento, que tendem a separar gradualmente os seres humanos dos espaços que estes ocupam. Tal separação resulta num desinteresse que dificulta nossa capacidade de transcender julgamentos metropolitanos, intolerantes e parciais acerca do futuro de países, como o Brasil, em desenvolvimento, e, talvez, ferramentas 
artísticas como a literatura são as únicas capazes de ampliar nossas reflexões por nos pedir para ir além de perspectivas preconcebidas. Este artigo objetiva demonstrar como Milton Hatoum, no romance Dois irmãos (2002), deixa implícita a necessidade de se buscar possibilidades distintas para desenvolvermos nossos espaços, mais especificamente a Amazônia; e, através da análise do livro e do impacto do desenvolvimento na região, o diálogo entre literatura e natureza é proposto. Primeiramente, a abordagem teórica sobre natureza e literatura é introduzida, acompanhada de uma discussão sobre a importância de se (re)conectar sujeito e meio ambiente, e, em seguida, a análise dos personagens do romance, que demonstram os efeitos colaterais do "progresso" e "crescimento" da região Amazônica. O resultado é a problematização de dicotomias normativas como selvagem/ civilizado, passado/futuro, sujeito/espaço e subdesenvolvido/desenvolvido; e a conclusão de que, para que o desenvolvimento deixe de ser pernicioso para com a natureza, é necessário evitar acreditar-se em um "meio ambiente sem rosto" (Campbell, 2010, p. 18); isto é, é preciso observar o impacto de tal desenvolvimento na vida daqueles inevitável e automaticamente marginalizados por ele.

Palavras-chave: literatura; desenvolvimento; meio ambiente.

"The Earth is a very small stage in a vast cosmic arena. Think of the rivers of blood spilled by all those generals and emperors so that in glory and triumph they could become the momentary masters of a fraction of a dot. Think of the endless cruelties visited by the inhabitants of one corner of this pixel on the scarcely distinguishable inhabitants of some other corner. How frequent their misunderstandings, how eager they are to kill one another, how fervent their hatreds. Our posturing, our imagined self-importance, the delusion that we have some privileged position in the universe, are all challenged by this point of pale light. Our planet is a lonely speck in the great enveloping cosmic dark. In our obscurity - in all this vastness - there is no hint that help will come from elsewhere to save us from ourselves."

Carl Sagan (Pale Blue Dot, 1994)

\section{Society, development, and ecocriticism: what does literature have to do with nature?}

"Through literature, ecocriticism can go beyond connecting readers with nature and analyze what constitutes those connections" (Campbell, 2010, p. 19). Andrea Campbell, in the article "Reading Beyond a Universal Nature: Hopes for the Future of Ecocriticism" (2010), poses that "since its formal inception in the 1990s, the field of ecocriticism has experienced dramatic growth and dramatic changes"; and this graduate growth of Ecocriticism, followed by its conceptual evolution, is essential for contemporary beliefs that disregard the connection human/nature to be evaded, possibly, retransformed.
The task is not an easy one, and surely "the twenty-first century looks to be a time of excitement and challenge for ecocriticism" (Campbell, 2010, p. 1). Given that situation, the anthropologist David Harvey (2000) poses that literature should provide us with bridges to see how the world is interconnected, and not make us even more anthropocentric. Therefore, simply saying that "literature about nature" would be the solution for environmental issues is ingenuous, since one can write about nature as if from the outside, ignoring human connections with it-or overemphasising natives' connection with it, what might be even worse. This, in his view, is a tendency of Western tradition: to narrow down our focus to the inner meanings of isolated things-as if in locked boxes-such as humans and the environment. This is due to a contemporary Western illusion that convinces us that the more we narrow down our focus the better we can see.

This author, like many others, makes it clear that the meanings of both nature and human cannot be understood without taking into account the interactive relationship that exists among such things. In "Responsibilities Towards Nature and Human Nature", a chapter from one of Harvey's most well-known books, Spaces of Hope (2000), Harvey's view is that, even though hegemony addresses ecological matters as if everything required to solve current environmental issues is a more cautious approach towards nature while the west "grows" (that is, we just need to develop "more carefully"), western capitalist and expansionist system is bound to fail in that attempt due to the self-destructive character that defines this system in the first place. In order to rethink 
human relationship with nature effectively, Western structural projects - mainly the ones related to its notions of progress and development - cannot be applied less harmfully, they need to be completely discredited and rethought. As one of the most respected theorists in the field of social sciences, David Harvey's positionings have marked him as hugely antagonist when placed before the neoliberal and profiteering global market, whose main axioms are problematised by the author through several of his analyses regarding mainly neo-imperialist enterprises. His writing, therefore, is permeated by a sense of social and political justice, and, when addressing those issues, the environment is a topic in which he seems to be particularly interested.

Even though he has never called himself an actual "ecocritic" that does not mean he is not; he surely has much to contribute to the field, and the fact that he is not labeled as an ecocritic does not affect the ecocritical plausibility of his arguments. Here I rely more specifically on these arguments as found in two chapters from two different books that he has written, both focusing on nature and/or on human relationship with nature. Criticising the basic tenets of neoliberalism, Harvey believes that, to exercise these powers "we have accumulated", Western imaginary needs new ways of experiencing nature; if the ideological structure of the system is not changed, then nature will still be deemed as a romanticised space that can be either controlled or saved by our human supposed wisdom. Ecological discussions, no matter how trendy or recurring, are generally much more complex than we think, and especially in what concerns western culture, fairly dependent on an influential socio-political and economic bias.

Phillips is strongly against such idyllic and innocuous appreciation of nature "as nothing more than projective fantasy or social allegory" (1999 p. 584), and she criticises its construction as a paradisiacal realm, or an illustration of human feelings. According to the researcher a less anthropocentric view on the matter is required: "one can treat literary texts not as detractions from but as contributions to our interaction with the natural world". Ecocritical writing must not aim at giving readers an escape from the material world, but at giving them tools to face up to such world as much "more than 'an ideological screen"” (Phillips, 1999, p.
584). Furthermore, Harvey poses that, for the Western tradition, commodifying everything and subjecting almost all transactions, including those connected to the production of knowledge, "to the singular logic of commercial profitability and the cost-benefit calculus is a dominant way of thinking" (Harvey, 2000, p. 222). Such "dominant way of thinking" is a hindrance for other logics to be devised and put into practice, since everything that does not aim at generating profit is hampered by the "cost-benefit calculus".

In Phillips' (1999) view, the greatest asset of ecocriticism, regardless of its contradictory existence, is the theoretical holism it implies. If one thinks of analysing nature through clearly separated steps, like hegemonic thinking implies, the possibility of an accurate result becomes much foggier than it would if the whole had been considered. The science of ecology confirms the indivisibility of natural processes: "each feature of a landscape must be understood with reference to the whole, just as the habits of each creature reflect, and depend upon, the community of life around it" (Phillips, 1999, p. 581). Nature does not constitute itself in an isolated manner; the interdependence and interaction between the parts is unavoidable, and taking that into account is of paramount importance for the theory to make sense. In the words of Harvey, the environment "is now an open and critical focus of discussion and debate among the capitalists and their allies-many of whom are obsessed with the issue of long-term sustainability" (Harvey, 2000, p. 213). The theorist admits, thus, that people have been concerned about our relationship with nature - which has already proved to be far from healthy - but he nonetheless does not believe that talking about it from the same Imperialist perspective, which has accompanied us throughout history, is quite enough.

Trying to "change" capitalism to become less damaging to nature is impossible; if everything is seen through the lenses of profit how can anything be preserved? This is why Harvey believes that this "long-term sustainability" - so fashionable in the contemporaneity is nothing but utopian if the structural flaws of the system are not amended; a money-centred society-exactly what we are-is essentially the antagonist of a sustainable one. One of these structural flaws of the capitalist system is the anthropocentrism it entails. Some of us have actually 
been convinced that we should not worry so much about how the west has altered the environment because the environment has always gone through modifications, that there have been ice ages and fire ages so the weather has always been naturally unstable just as it is today, that forests are useless and buildings are necessary, etc-so we can basically do whatever we want no matter the consequences. This is all an attempt to withdraw human responsibility to deal with the problems we have created. However, Harvey warns us that, notwithstanding the fact that other communities and even animals might have disrupted nature's functioning in one way or another, notwithstanding the fact that the weather is indeed unstable, no one has had so much impact on the planet as western culture has; it is, then, our responsibility to engage in reflections that address the issue as a whole: "we are now obliged-by our own 'achievements'-to work out in the imagination as well as through discursive debates our individual and collective responsibilities" (Harvey, 2000, p. 213).

Not with standing the fact that other species work for their own survival to be guaranteed, humans must, from now on, look for answers "not only to ourselves and to each other but also to all those other 'others' that comprise what we usually refer to as 'external' nature-'external,' that is, to us" (Harvey, 2000, p. 213). Here the researcher problematises the idea of an internal and external nature (human nature and nature in general), suggesting that boundaries separating those realms are much more cultural than indeed natural. Although Harvey strongly criticises the destructive historical record of Western contact with nature, this conclusion is pretty Marxist; that is, his argument is that the ability we have to be detrimental to nature can be balanced with the one we have to be positive to it (what we used to harm nature would be used to try and help its preservation, such as communism would be the "fair" use of capitalist triumphs after its dethronement). It is obvious today that human beings can change the world. The point now is how and why to do it less egocentrically: "we have accumulated massive powers to transform the world, and the way we exercise those powers is fundamental" (Harvey, 2000, p. 213).

In Harvey's view, Western thinking should overcome this cost-benefit calculus that it does every time it addresses a problem. The importance of nature has nothing to do with its profitability; on the contrary, this calculus will always result in more destruction and destitution; the marginalised lives will always change for worse as long as the calculus is done based on the production of our environmental difficulties. Both for the marginalised and the impoverished it "is consequential upon this hegemonic class project, its market-based philosophy and modes of thinking that attach thereto" (Harvey, 2000, p. 222). Environmental degradation is, therefore, the natural result of this "hegemonic class project", a project that must not be remodelled, but completely abandoned and started from scratch. Concerning that matter Harvey has a very ecocritical opinion when it goes to how a distinct project could be devised anew; the author sees in literature a very good opportunity to address ecological matters as to make the reader evade hegemonic thinking. However, concerning the traditional literary approach on nature, he criticises the alienation of readers through books that discuss the human "self" as if it were isolated from nature and/or from the "Others".

Much of the literature of our time, he claims, has been dominated by the quest to understand the inner self and to understand even whole symbolic systems in terms of their inner meanings, "but this quest to understand inner meanings is inevitably connected to the need to understand relations with others" (Harvey, 2000, p. 223). Moreover, concerning this "widening gap" in fiction, Campbell has a very strong and critical view on novels, poems, and etc., which highlights the supposed superiority of the human mind without taking into account the space that is occupied by such humans: "fiction that never looks beyond the human realm is profoundly false, and therefore pathological. No matter how urban our experience, no matter how oblivious we may be toward nature, we are nonetheless animals" (Campbell, 2010, p. 3). Ecocriticism would be, then, a very effective approach to dodge such inaccuracy since its main feature encompasses the desire to make the environment more central to literary discussions, "to reconnect readers with nature, and to downplay the importance of strictly theoretical discourse, all in the hopes of combating environmental destruction" (Campbell, 2010, p. 4). 


\section{The land and the subject: what do we have to do with nature?}

Drawing a parallel between marginalised peoples - who fight for their "personal and social agency" - and land, "blurring the boundaries between self and nature", does not result in a deviation from the main tenets of ecocriticism; it only calls into question what the author considers as the idea of a "faceless environment": "where it is only nature that suffers from harmful effects" (Campbell, 2010, p. 18) of development. The unpleasant outcomes of environmental destruction does not affect only the land, but also everyone else living on it, and "focusing upon texts that incorporate racial, ethnic, class, and sexual difference, and/or that emphasize intersections between social oppressions and environmental issues" (Campbell, 2010, p. 12) would be a pivotal step for Ecocriticism not to be deemed "faceless" any longer.

Hegemonic worries are ultimately comprised only by problems that affect hegemonic purposes. As a result, marginalised populations are not seen as participants in this process, at least not as "active" participants since what the system needs is their passivity. Seen by hegemony as part of the problem, and not the solution, the way the margin is affected by the environmental impacts of Western "development" is not a problem at all, and it does not deserve attention:

Matters are far from simple. To begin with, the definition of 'environmental issues' often entails a particular bias, with those that affect the poor, the marginalised, and the working classes frequently being ignored [...]. [E] nvironmental global impacts frequently have a social bias - class, racial, and gender discriminations are evident in, say, the location of toxic waste sites and the global impacts of resource depletion or environmental degradation. [...] Finally, the distinction between the production/prevention of risks and the capitalistic bias towards consumption/commodification of cures has significance (Harvey, 2000, p. 221).

Therefore, everyone whose "class, race, and gender" deviate from the main patterns devised by hegemony can and must be ignored for the system to thrive. Normativity does not deem them intellectually capable of knowing more about nature than hegemony does. Indeed native communities are generally much more unawareand this is not a synonym for insouciant-of how human beings can be detrimental to nature. However their way of life has "naturally" been permeated by a balance that our hegemonic culture can never reach as long as our commodification and commercialisation of nature is not stopped. For society's contact with nature to become indeed more than this "ideological screen" it would be profitable to engage in dialogues with other theoretical areas, which can function as ideological resources for it to enrich its revolutionary features: "ecocriticism needs a rationale that will enable it to use the "resources" of literary theory while retaining some respect for the force of theory's premises, for it is surely the case that the premises of theory are its resources" (Phillips, 1999, p. 585). There must be "respect for the force" of these resources. If Ecocriticism is unable to become open for theoretical resources regarding marginalised realms other than nature, "the result can only be a middlebrow literature of nature informed only by middle-class values, and too much contemporary nature writing is like that already" (Phillips, 1999, p. 587).

In the chapter "Creative Destruction on The Land", from the book The Enigma of Capital and The Crisis of Capitalism (2010), Harvey shows his readers that, at the same time we destroy and change our milieu-"while the Amazonian rainforest burns", we are able to lie to ourselves by pretending our society is being able to live balancing human lives with environmental preservation-while our "government announces a vast programme of reforestation" (Harvey, 2010, p. 184). In order to illustrate his view that Western tradition is essentially anthropocentric, he compares our culture with the ones of some marginalised peoples who seem to understand their connection with the land to be much less hierarchical than we seem to think of ours. The Apache believe that wisdom sits in places, and indigenous groups everywhere, "from Amazonia to British Columbia and the mountains of Taiwan, celebrate their long-standing and unbreakable bond with the land wherein they dwell" (Harvey, 2010, p. 184). The fact that western tradition lacks this "bond with the land" that such communities have been able to foster is undeniable. Moreover, even after we have experienced the consequences of our acts, 
Harvey suggests, our behaviour is still as or more damaging, even if euphemistically rearranged.

Over the last three centuries marked by the rise of capitalism, the rate and spread of destruction on the land has increased enormously; "we are more circumspect now in our rhetoric, though not necessarily in our practices" (Harvey, 2010, p. 185). We do not need profitable places or relationships in order to be deemed spatially and temporally meaningful; our spatial and temporal configuration does not need to be profitable in order to be comfortable. Ultimately, comfort can only be achieved by humanity-whose lives tend to focus on an ultimate happiness that is never accomplished due to the pathologic functioning of our capitalist structure-if we stop believing that money is the answer for every question. Nevertheless, the system is able to effectively sell the idea that it is through market that happiness, the feeling of living a satisfying life, can be effectively achieved, although in fact it takes us to the opposing corner. There are no "naturally advantageous" spaces for one to be, these are generally economically advantageous for the market and the state, which seems to be always benefiting neoliberal interests, even though such interests go, controversially, completely against the whole reason for the state to be: " $[t]$ he neoliberal movement [...] constitutes a radical ideological assault upon what the state should be about" (Harvey, 2010, p. 196). What Harvey means is that global spaces are generally measured by their economic strength, by their ability to profit, and this is not necessarily what the state should be doing for us.

Campbell believes that, for us to be given some of this less normative "sense of place", "race, class, gender, and sexuality are important issues for the future of ecocriticism [...]" (Campbell, 2010, p. 16). The possibility of interdisciplinarity as an interesting path is addressed, which also comes during this second-wave of ecocritical thinking-since the first was comprised mainly by "personal narratives about nature produced from privileged positions of gender, class, and ethnicity" (Campbell, 2010, p. 8). In Campbell's view, pondering upon the land as connected to other margins, as connected to marginalised peoples, allows the field to finally connect social justice with environmental issues. She poses that "[p]erhaps what has been most troubling for critics of first-wave ecocriticism is its lack of engagement with issues of race, gender, class, and sexuality" (Campbell, 2010, p. 7); ignoring people who have been marginalised by hegemony, ecocriticism has endorsed and promoted "a false sense of separation between social justice and environmental issues" (Campbell, 2010, p. 8).

Ultimately, environmental matters are much more connected to our daily lives than we are prepared to accept. Nevertheless, contemporary romanticism towards nature has provided us with a "Utopian environmentalism" that sugarcoats our detrimental use of natural resources. The reason is simple: in order not to face the poignant reality Western tradition has generated, we have created an artificial-however pleasant-cosy milieu that reminds us of a nature we do not think is "needed" any longer; and that has made it difficult for us to try and look beyond "the landscape of capitalism" (Harvey, 2000, p. 231). The only ones who benefit from Western progress are, in the end, rich investors, since the purpose of neoliberalism being inserted in previously non-developed places is "to redistribute wealth and redirect capital flows to the benefit of the imperialist or hegemonic power at the expense of everyone else" (Harvey, 2010, p. 207). Though what seems to be a discursive and procedural juggling, capitalism debars natives from their own land, and finally imposes a new way of life in a brand new space - that was once theirs - they would never be able to leave the margin wherein they have been placed; having been taken their own space, the west makes the invaded start feeling as if they were the invaders. It is cruel, but effective.

\section{3. "Out of place and time": the oosition of the Amazon in the globe}

Gomides and Vogel, in the book 'Amazonia in the Arts:' Ecocriticism versus the Economics of Deforestation (2007), emphasise the importance of thinking ecocritically about the Amazon, whose rates of deforestation "are surpassing historic records" (Gomides \& Vogel, 2007 , p. 2). When problematising Western notions of development in the region and criticising the never-ending habit of hegemony to impose its will everywhere it gets, the researchers work on "the theme of accepting the Amazon on its terms" (Gomides \& Vogel, 2007, p. 56). 
They believe that one of the most important questions of contemporaneity is if the Amazon "can pass through the bottleneck of 'economic development' without deforestation" (Gomides \& Vogel, 2007, p. vi).

The Amazon is an emblematic locus of the hegemonic discourses and the master narrative of modernity against which it is described as a land that has been lost in time and isolated in its space. What this normative discourses suggest is that if "development" reached those lands things would improve for their "abandoned" populations. Is that so? In the opinion of Galeano (1997, p 249-250) the growing relative backwardness of the great hinterlands, submerged in poverty, "is not, as some maintain, due to their isolation, but on the contrary to their direct or indirect exploitation". Studies endorse what Galeano poses: poverty, as I have already suggested, is a necessary means for richness to exist.

The background of The Brothers (2000) brings, among other things, this problematic dualism that seems to occur due to the colonisation and neocolonisation of the Amazonian region, natives' Westernisation, land exploitation, cultural suppression, the complex love/hate relationships in the family scope, and the needs and wills of Amazonian marginalised characters that are repressed by industrial interests which gradually overlap their once simple way of life. The dichotomy between industrialism and savagery is, ultimately, pivotal. Nael, the narrator, observes two of his masters as representatives of both realms and throughout most part of the novel hopes to find out he is Yaqub's (the educated, Westernised one, who criticises his father for his friendly non-commercial behaviour with his customers in the family's shop) son, since his manners and posture are attractive and inviting, whereas Omar's odd habits, lack of prospects, and irresponsibility when compared to the main social patterns make him unappealing.

One could say that Nael's preference and possible narration bias for the "civilised" brother (in the novel the reader should not forget that intra-diagetic focus is not supposed to be taken as reliable), and the fact that he later finds out that Omar, the savage, was actually less harmful than Yaqub, are already hints that the novel's purpose is not to endorse normative epistemologies and hegemonic discourses regarding patterns of identity; on the contrary, Hatoum seems to be trying to do the opposite. The family that foregrounds the novel's space (composed by the parents Halim and Zana, immigrants from Lebanon, and by their kids: Yaqub, Omar, and Rânia) is seen, thus, through the eyes of a slave/servant, the son of an Amerindian bought from the church when she was still little, with one of the two eponymous twin brothers, Omar and Yaqub - mystery that persists until the end of the diegesis. The Amazon and the family as portrayed by the narrator seem to be constructed by the leftovers of a past that has been obliterated, just like the characters' lives themselves; they are the shadows of the Indian, the shadows of the immigrants and their culture. Their identities are neither savage nor civilised: they are both, and they are none.

Moreover, Nael's observations regarding the commercial revolutions going on in Manaus seem to grow pretty skeptical, since they do not pinpoint how distinct paths nature and city are taking in the region, but how their conflictive interaction is effectively taking place, highlighting not only what has been built but also what has been destroyed in the "development" of the Amazon. Such changes apparently occur in the social realm, when Nael describes how human relations are affected by the emergence of neoliberal commerce in the region, wherein friendship and compassion do not apply for they hinder the thriving of business, and also in the physical realm, when he contemplates how the forest endeavours unsuccessfully to coexist within that artificial milieu gradually inserted in the region by its industrial insertion in the globalising world map.

Hatoum's spatial and temporal narrative is alloyed with regional, national, international, and historical memory fragments. The novel conveys a tone of characterisation that manifests the rejection of narrow plus superficial and abstract illusive experiences while it is also willing to discuss social conflicts, which have been regularly ignored by such experiences. Confined in the present The Brothers besieges the concealed past, while striving to spot the future. The Amazon, it is important to mention, is not where Hatoum's voice is restrained, but where it is emancipated. His voice is represented by the voice of the characters, who are, in their turn, liquid fragments of a liquefied time; they are what is left: what is left of the Indians, what is left of a never-ending past. What Nael's observations demonstrate in the macro level 
is how problematical and controversial the concepts of progress and development in the North of Brazil are. Situated in the outskirts of capitalism, the Amazon as observed by the narrator raises matters which concern not only the region but a whole world where development, progress, and modernisation do not seem to respect any ideological borders, shaping the contradiction that moulds the core of contemporary reality.

The symbolic contrast between Yaqub and Omar is immeasurably pertinent for the progress/backwardness of the novel, since it seems that the opposing roles played by Omar and Yaqub can only be effectively linked through the ideological bridges created by the narrator's insights. Living at the moment when the exploration of the Amazon starts assuming its most commercial shape, Nael's story starts side by side with Brazilian story of progress, side by side with ideas of modernisation and improvement, which are taking place in a society crammed with "half-slaves" (who, just like Domingas, Nael's mother, work to live and live to work) where extreme poverty and lavish wealth are able to coexist in purportedly perfect harmony. It does not take long for Nael to discover that Yaqub, the symbol of future and modernisation, the educated engineer of this new society, is not the ideal man he imagined, but a cold, self-seeking, person, who is able to abandon his family and everything that had been valuable to him in the name of the progress and development promoted by the educated people of his future, but hindered by the supposed savages of his past.

Yaqub's "development" is similar to the Amazonian one: disguised with the illusion of "improvement", when the Amazon goes through development it is not its conditions that are enhanced, but the tentacles of the social dominance which determine its destiny. The effects of Westernisation are mesmerising insomuch that, in the words of Escobar (2009, p. 438), certain types of social dominance may be analysed as the product of the interconnection among the introduction of dominant discourses about the economy, their inscription in institutions and practices (e.g. through development), and their effect on local historical situations, "including the resistance to these processes". As mentioned before, development interferes not only in the economy, but also in many other "institutions and practices"; it alters the "historical situations" of the Amazon, and result in diverse forms of "resistance to these processes".

In the novel, if Omar embodies this "resistance", Yaqub is the character that impersonates "these processes"; that is, development and the thirst for profit and expansion. When he starts earning money his values become a commodity, and he does not send money to his family because that is the only thing he could do for them, but because that is the best thing he thinks he could do. The reader shall not forget that when Yaqub leaves Manaus, in the beginning of the novel, he does it "quietly, leaving the house where he had lived with frugality and discretion. He had hardly occupied the place, hardly more than a shadow" (Hatoum, 2000, pp. 36-37). Even before leaving the city for the first time, it is as if Yaqub had never belonged to Manaus; he has never been an Amazonian, so to speak, or that is the impression one has due to his total devotion to capitalism, which withdraws people's abilities of becoming attached to their land, their ability of "occupying the place" as "more than a shadow".

The brother, who has never seemed to belong to the Amazon, is excluded by himself and by the others, being ultimately and literally sent away to avoid further conflicts between Omar and himself. Halim, the brothers' father, has never acknowledged any drawback in strengthening Yaqub's detachment with his family and city, with his time and space. Still believing in the romanticised hegemonic discourses, the father was daydreaming of a glorious future for Yaqub, "and that was more important than his return and stronger than the separation. Halim's greyish eyes lit up when he talked about it" (Hatoum, 2000, p. 37). But here, already, the narrator foreshadows the fact that Halim's faith in this "glorious future" will not last forever: "I saw those eyes many times, not lit up like that, but not dim either; just tired of the present, and with no future of any kind in their sights" (Hatoum, 2000 , p. 37). Again we get in touch with some more of Halim's resignation; Nael's observation seems to find no place and time where Halim's eyes could fit in. In a way the brothers' father becomes progressively aware that his past is being killed: that makes him dispassionate or rather, what is even worse, "tired of the present" and with no prospects about his future. 
In this future money reaches soaring proportions not only in Yaqub's life but also concerning his relationship with others; when the brother returns to Manaus he is able to remain detached from the city and its people, even though he is able to coexist pacifically with them: "Yaqub was almost formal in his behaviour; his attitude to the neighbours was humble, friendly without being effusive" (Hatoum, 2000, p. 112). Nael notices that there is some air of superiority on the brother's aloofness, his rich and developed life was far more important than that of a mortal caboclo. Actually the narrator realises that Yaqub's condition is pretty privileged if compared to several other people: "he said nothing about engineering, or his own feats. There was no need: everything in his life went so smoothly". The narrator claims that "the upsets and the purgatory of daily existence only happened to other people. 'Other people' meant us: us and the rest of humanity" (Hatoum, 2000, p. 112).

On the one hand, Yaqub's life was so busy, his financial worries so imperative, that "the purgatory of daily existence" did not deserve any of his attention. Existing was only a problem to be addressed when it concerned the "other people", those who, like Nael, are not centralised; not a few "minority" but actually "the rest of humanity". Omar, on the other hand, is unable to accept the fact that, as Galeano (1997, p. 247) puts it, "development is a banquet to which few are invited", and, therefore, cunningly steals money from his brother and travels to the US in order to see with his own eyes if this development is really worth it. When Omar decides to undertake such adventure, Yaqub, who so capitalistically learns to save all the money he makes instead of spending it as his father usually did, has to handle Omar sending postcards from every city he visits, making fun of Yaqub and his wife and ridiculing their habits and ambitions. Surprisingly, when Yaqub tells his father all that has happened, Halim becomes mad not at Omar's behaviour, but when he realises what has happened to Yaqub, what the glorious future of his son has turned him into:

Omar sent the first postcard from Miami; later he sent others, from Tampa, Mobile and New Orleans, recounting the fun and games he'd had in each city [...]. 'Dear brother and sister-in-law, Louisiana is America in the raw, really rough, and the Mississippi is the local version of the Amazon. Why not take a little trip here? [...] If you come, be sure you dye your hair blonde: that way you'll be one of the elite. Brother: your wife, who's been pretty in her time, might look really young with toasted-blonde hair. And you can make a lot of money here in America. Cheers from your brother, Omar' [...]. 'He stole my passport and went to the United States. My passport, a silk tie and two Irish linen shirts!' [...] What's the best thing to do when a son, a relative or anyone else makes a fuss over money? Do you know? [...] For heaven' sake, all I want to do was to forget all this garbage, the eight hundred and twenty dollars, the passport, the tie, the shirts and bloody Louisiana (Hatoum, 2000, pp. 117-120).

Omar's sarcasm unnerves his brother, since he takes everything that is deified by Yaqub and turns it into a joke: his money, his efforts to succeed, his pride, and his marriage. Even the appearance of the couple is turned into a mockery; according to him, Yaqub and his wife should dye their hair blonde when they go to the US so they can "be one of the elite". What seems to be implied by such comment is the ultimate superficiality of Western values since, in the end, even with all its supposed technological, ideological, and commercial superiority, all its significance, the fake armour that purports to protect its legitimacy, can be reduced to superficialities. Omar is, therefore, enjoying his superficial happiness in a place that was not meant for him. Certainly Omar's attitude is taken as contemptible by his father - who could praise a son that steals money from his own brother? However, what actually bothers him is Yaqub's obsession with materialism-what becomes clear by his fuming reaction after the event. Like Omar usually did in Manaus when he lived with his parents, so he does in Sao Paulo living with Yaqub: he finds money and he spends it, as simply as that. Stealing and spending money that does not belong to one is not something to be praised whatsoever, but the logic of capital accumulation does not fit in Omar's or Halim's manner of understanding life, and Yaqub would never be able to understand that.

Yaqub, as most of us, is not the villain, he is also a victim, a huge victim of the system. These binarisms (victim/villain, savage/civilised, past/future), as I show, become difficult when one tries to ponder upon such facts 
carefully, since mostly conclusive dichotomies do not seem to be fairly accurate. But what the reader might ask himself after reading this excerpt is: would Yaqub ever travel to the US? Would he ever have the time or interest? Would he ever "waste" money with a tourist trip? I do not know, but do not think so. It is interesting, but the fact that Omar is not meant to do what he did is exactly what allowed him to have done it; the capitalist way of life, so inserted in Yaqub's mind, convinces people that they must earn money, save money and, after that, enjoy life; but even when people have money they must earn much more, endlessly more, in order to save more to, after that, enjoy life "better". However, this last step is never reached, it is not meant to be; Yaqub is the kind of person who is sentenced to work his whole life without ever asking himself the purpose, without ever trying to enjoy one single moment. For Omar it is much simpler.

Son and father are already living in what seems to be a distinct temporal condition. As stated by Halberstam (2005, p. 7), "[T] o all different kinds of temporality we assign value and meaning [...] according to the logic of capital accumulation, but those who benefit from capitalism in particular experience this logic as inevitable". The temporal condition of Hatoum's characters, hence, can be understood to be neither distinct nor inevitable, even though normativity poses that they belong to different temporal spheres. When going to the US and becoming inserted in "the future", Omar shows the readers that one can travel through the gaps of time and space, belonging to the past, the present, and the future and to none at the same time. Yaqub is obviously benefiting from his hard work, from capitalism, and he cannot accept the actions of his brother. In fact, the existence of variations to a system that bases itself on a premise that emphasises its universality is not acknowledged whatsoever.

Halberstam believes that if we destabilise the meaning of capitalism then we can begin to see the multiplicity of non-capitalist forms that "constitute, supplement, and abridge global capitalism, but we can also begin to imagine, by beginning to see, the alternatives to capitalism that already exist and are presently under construction" (Halberstam, 2005, p. 12). Here we can ponder upon the importance of thinking about the queer spatiality and temporality of the postcolonial subject. According to Hall (1996, p. 248) the postcolonial signals the proliferation of histories and temporalities, and "the intrusion of difference and specificity into the generalizing and Eurocentric post-enlightenment grand narratives". However, the author thinks that the postcolonial per se is not enough for us to think about identity since we should also take into account other theoretical examples, where the deconstruction of core concepts undertaken by the so-called "post" discourses is followed, "not by their abolition and disappearance but rather by their proliferation, only now in a decentred position in the discourse" (Hall, 1996, p. 248). In this sense, the cultural condition of the postcolonial subject represented by Omar, Halim, and Nael is what preconditions and stigmatises these characters as temporally or spatially settled in a certain region and time. Therefore, as to understand time in a distinct and non-normative manner, acknowledging its status as liable to being interpreted and redefined recurrently by human intervention, we should first redesign our mode of understanding the postcolonial and, more importantly, of understanding culture itself.

In the words of Fabian (1983, p. 24), as soon as culture is no longer primarily conceived as a set of rules to be enacted by individual members of distinct groups, but as the specific way in which actors create and produce beliefs, values, and other means of social life, "it has to be recognized that Time is a constitutive dimension of social reality". When Omar goes to the US with Yaqub's passport he disrespects this "set of rules", he disrespects time "as a constitutive dimension of social reality" since he was not allowed by the system to do what he did; hence the benefits of capitalism he enjoys are not meant for people like him. Hatoum seems to play with this idea of not belonging to where or when his characters are when Halim tries to evade his temporal condition by staring at the Amazon's nature in an attempt to ignore his existence in what is normatively deemed as the future of what he observes:

Sometimes Rânia invited two acquaintances to play in the little upstairs room, just so that her father would [...] not stick his nose into her business, though he took practically no interest in the fate of the shop [...]. [H] e soon turned his face away to the bay of the Negro, looking for calm in its waters and the huge white clouds mirrored in them (Hatoum, 2000, p. 181). 
In fact, at the beginning of the novel, Nael foreshadowingly happens to describe Halim as someone who seems to have always been "a little out of place and time". This is the moment when the reader gets knowledgeable about Halim's difficulties when leaving the Lebanon and coming to the Amazon, following the romanticised reports about a magic land of great opportunities and unmatchable prospects: "he suffered, like many other immigrants who had come with nothing more than the clothes on their backs. Drunk with idealism, he believed in ecstatic, passionate love, with every metaphor under the sun-or the moon" (Hatoum, 2000, p. 44). And it is also at this moment when we begin to understand that, notwithstanding the similarity of Halim's history with that of others if compared to the context of the several immigrants who came to the Amazon at that period, the personality of this character can and shall certainly surprise us: "he was a late-flowering Romantic, a little out of place and time, indifferent to the power of money, whether honestly or dishonestly come by."

Nael believes that "perhaps he could have been a poet, a minor provincial flâneur; but all he was was a modest shopkeeper possessed by a consuming passion. That was his way, and that was the way I knew him" (Hatoum, 2000, p. 44). If getting in the Amazon Halim's profession was that of "a modest shopkeeper", this was not the reason for him to abandon his "consuming passion", not only for his wife, but also for everything in his life. His "indifference to the power of money" made him able to feel completely accomplished without being rich. But, since capitalism requires us not to be accomplishedactually even if we have a lot of money- when modernity comes, Halim becomes a man "out of place and time".

This is why Rodríguez introduces the idea of thinking about a "queer sociality", which is at its core an attempt at recognition: "It is a utopian space that both performs a critique of existing social relations of difference and enacts a commitment to the creative critical work of imagining collective possibilities" (Rodriguez, 2010 , p. 332). Only then can the temporal and spatial situation of distinct cultural productions be understood as part of our present, and not of our past. But this is the moment of the novel when Yaqub's revenge becomes inevitable, he waits for his parents to die and collects all the evidence he has against his brother, using his influence and power to carry out the actions to which he has eagerly longed:

Rânia soon realised that her brother, in São Paulo, had engaged lawyers and was coordinating Omar's persecution. [...] Little by little, she discovered that her distant brother had calculated the right moment to act. Then, like a panther, he pounced. [...] Some years later, one day early in April, [...] it was already spitting rain when Rânia caught sight of him [Omar] in the Praça das Acácias. [...] There were three police men, then five, then a lot more. It was a hunt. [...] Did they want to kill him or just give him a fright? [...] The rifle-butt he got in the face was the beginning of his entry into hell. He fell back and was pulled, dragged to the van. [...] The morning he came into court, escorted by the police in plain clothes, [...] she [Rânia] heard him recount a sudden descent into hell. The days were the same as the nights, and every day a darker prolongation of the night. [...] Sometimes, in the small window in the wall, the frond of an açai palm moved, and he imagined the sky and its colours, the river Negro, the vast horizon, freedom, life [...]. [I]n the solitude so essential to her [Rânia], in her old maid's permanent seclusion, she wrote to Yaqub what no one dared to say. She reminded him that vengeance is more contemptible than forgiveness. [...] Yaqub, rejected and resentful, was also the most brutish and violent of the two, and would be judged for that [...]. Yaqub calculated that silence would be more effective than a written reply [...]. In the end the madness of Omar's passion, his excessive hostility to everything and everyone in this world were no less harmful than Yaqub's plans: the danger and the sordid underside of his calculating ambition (Hatoum, 2000, p. 256-264).

Again we have the image of a "hunt", it is the system hunting the unfitting Omar, who has not learned not to disrespect the epistemes of progress and development. The free, unrestrained, unregimented, and unimpeded brother has to handle experiencing the Amazon-to which he has always been so attached-through a "small window in the wall". Nevertheless, even though being in this condition, Omar was able to imagine or to remember "the sky and its colours, the river Negro" and everything else that Yaqub has so early forgotten. Interestingly enough, even arrested Omar sounds ideologically more unhampered than Yaqub. 
The narrator was already becoming increasingly suspicious towards Yaqub since the beginning of the novel, for, since he was a kid, Yaqub's obsession with study and work was already something regarded as a bit weird: "Days and nights he spent in his room, never going for a plunge in the creeks, not even on Sundays, when the people of Manaus come out in the sun and the city makes its peace with the river Negro" (Hatoum, 2000, p. 22). But it is especially after he returns from Sao Paulo for the first time for a visit that Nael starts asking himself who Yaqub really was. According to Nael he was clearly assuming a more refined character, and "wearing the camouflage of everything that was modern about the other side of Brazil". But, for wearing this camouflage, the narrator poses that Yaqub, like "a worm that wants to be a snake [...], slid by silently under the foliage. Outside, he really had changed. Inside, there was a real mystery" (Hatoum, 2000, p. 53).

Rânia, the sister, who will regret having believed and endorsed many of Yaqub's actions, ends up experiencing what is hidden in that educated and civilised body and being forced to acknowledge the evil and putrefied side of that seemingly harmless "worm that wanted to be a snake". Both Yaqub and "progress" can easily deceive those who have known them superficially, but with a careful examination such an opinion that has so clearly divided the inferiority of ones from the superiority of others goes through a severe change, as I am attempting to demonstrate. When Rânia tries to find a solution for the brothers' quarrel and sends a letter, Yaqub calculates "that silence would be more effective than a written reply". This is exactly the kind of behaviour that powerful people - what Yaqub has been able to become - have: he ignores his sister, ignores his past and the suffering of the others; that is not different from what hegemony does with the marginalised Amazon and its marginalised inhabitants. Omar has to be arrested for he represents a danger; he is, like the Amazon, a representative of what Halberstam calls "the time of the other".

According to the author, a little more than technology and sheer economic exploitation seem to be left over for the purposes of explaining Western superiority: "It takes imagination and courage to picture what would happen to the West if its temporal fortress were suddenly invaded by the Time of its Other" (Halberstam,
2005, p. 35). When Hatoum describes what development destroys rather than what it constructs he endorses these deviances from the normative discourses that attest the supposed superiority of Western culture. Western "temporal fortress" leaves the Amazon in no time and place; "Western superiority" is not due to a higher quality of condescendence, but rather to the power to strike down and destroy; the West is a hunter, like Yaqub, that "pounces like a panther", preying on the game. Moreover, just like the hunter has to allure the prey through his/her disguises-which make him/her look as part of the hunting scenario-, so does Yaqub, who, by becoming so attached to the epistemology of development, cannot be disentangled from its epistemological axioms.

The Brothers' family is completely shattered by the "progress" that the mentioned "temporal fortress" protects: Halim dies, Zana becomes depressed, Omar is arrested, and Rânia as dispassionate about the future as her father was. How superior is a system that does that to people? In the end the only legacy of development for these few Amazonians and for their land is one of obliteration, forgetfulness, annihilation, and, ultimately, hopelessness. The general image of the novel is not one of gains, improvements, and enhancements; on the contrary: The Brothers is about the destruction of a past through the commodification of a future in our very present.

\section{Whose lives does development improve?}

Hatoum's characters see themselves forced to learn to live in the new condition that faces them in this same glamorous future in which Nael and Halim used to believe, and that Yaqub embodies until the end of the story. The house where the family had lived for so long gradually emptied, and aged in a short time. Rânia told her mother the move was inevitable, but "how could she [Zana] live without the cries of the fishmongers, coal-heavers, pedlars and fruit-sellers? "The voices of people who already in the early morning had stories to tell" (Hatoum, 2000, p. 245). The house that "gradually emptied" can be read as a metaphor for the Amazon itself, whose development is also deemed inevitable. The development of the region brings other habits, meanings, 
things, sounds; if Zana, Halim's wife, used to listen to the voices of friends and the cries of street vendors, now she will have to get used to the other sounds, the sounds of progress. The Amazon land, trees, and people are replaced by concrete, buildings, and machines. The house "aged in a short time", just like it has happened with Amazonian atypical existence which, "in a short time", is forced into the past. There will no longer be "stories to tell', in this promise of progress and development there is no time for talking, for chatting, for being. The sounds of the future supersede those of existence.

Rânia, after believing in the tales told by Yaqub, becomes controversially desperate to evade the future, she grows up and realises that things would be far more complicated than she once had thought; the future of the Amazon had much more to take from her than to actually give her, and she would have to handle it. She had bought a bungalow in one of the districts built on the deforested areas north of Manaus: "She wanted to live far away from there, and from the racket of the centre of Manaus. When there was heavy rain, there was total chaos at the Escadaria harbour and in the Rua dos Barés" (Hatoum, 2000, p. 245). The reader remembers when Yaqub said that "Manaus is ripe for growth", but he does not see this growth being beneficial to the region. Destruction has already taken place in "the deforested areas north of Manaus", and practically everywhere else, so, if capitalist construction depends on destruction, these processes have set the groundwork for construction to happen. But is it happening? Why was there "total chaos [...] when there was heavy rain"? These events take place because, gradually, they start to affect only an unimportant marginalised population of the city; this is a natural consequence of development, the elevation of hegemony, and even stronger marginalisation of the margin. Rânia, therefore, who was once so metropolitan, "decides to live far away from [...] the racket of the centre of Manaus." For her, dealing with the margin of society became worse than dealing with the margin of the Negro. Abandoned by her brothers, she has to learn how to do it with the help of Nael, who is only able to leave her in the end of the novel, when that "heavy rain" comes.

While he climbed on the roof to cover it with tarpaulin, Rânia tried to save the goods in the storeroom. On the pavements, "people who had just come in from up- river ate the leftovers from the Adolpho Lisboa Market. She gave them a few coins to keep away from the shop, but others came back and slept nearby" (Hatoum, 2000, p. 246). If time does not pass for these people, water does. Omar is like the Amazon: both have no prospects and no chance of fitting in a future that cold-shoulders the ones who are not willing to be "integrated". Omar's lack of desire to become civilised is like the Amazon lack of desire to become urbanised, both do not need the gifts offered by capitalism, they do not need to be modernised in order to feel more comfortable. Contrarily, Yaqub surely does. He has always been admired by his teachers and his parents, and his opinions have always been the most respected ones for fitting in the imaginary of an educated mind (and this is why he attempts to get rid of everything that had once made him an "Amazonian"). How could his family believe in such a disguise for so long? How can we? Galeano asked us more than 40 years ago, "Hasn't our experience throughout history been one of mutilation and disintegration disguised as development?" (Galeano, 1997, p. 277). Is not this the history of the Amazon?

The only way to rethink about such controversial concepts created and reinforced by a haphazard idea of a temporal progress and development-wherein money represents richness although its only consequence is destruction-is to understand the queer space and time of the Amazon as an opportunity for us to question Western positioning and to start anew an ideological search for not making the same mistakes we have been making for thousands of years. The condition of Omar and the imposition of Yaqub's portrayal as the one that should be reached by Amazonians are the tokens of the chronological imposition of hegemonic temporalisation and spatialisation. Nevertheless, the ambitions and defects of such portrayal disclose the mistaken assumption that such normative views on what one is and what on shall become is the only and best manners for evolving, developing, and moving on. The problematisation of Yaqub's "perfection", as a result, allows readers to rethink such chronology. In Halberstam's view “queer time and space are useful frameworks for assessing political and cultural change in the late twentieth and early twenty-first centuries (both what has changed and what must change)" (Halberstam, 2005, p. 4). 
Time and space are, indeed, "still the same", but Halberstam is right when she says we need new "frameworks for assessing" them, new lenses for understanding and effectively addressing "what has changed and what must change". The way we look at time and space might be fairly distinct, since both the observer and the images are never the same; or rather, what is observed, in the end, depends more on the observer and on the types of lenses he/she wears than on the landscape observed, since his/her eyes are what constructs such landscape as meaning whatever he/she wants it to mean. If we fail to acknowledge that the Amazon is neither in another space nor in another time, we will keep mitigating the revolutionary power of the only peoples and regions that can provide them; civilisation can only change its behaviour if it is able to accept the existence of different ones. The Amazon is not a pristine land that must be ignored, protected or abandoned; it is an epistemological possibility. However, if things keep going the way they are, there will always be this gap between past, present and future, especially in places like the Amazon, which embody the contradictions of the hegemonic system.

Our selfish manner of managing the temporalisation and spatialisation of the places where we settle and the peoples who we(st) institutionalise is exactly what puts them in the queer time and space where they are now. Amazonian "in-betweeness", in this sense, is already meaningful per se; its conflicting position in the middle of distinct temporal and spatial institutions is in itself a place for identity; the transitory condition of the Amazon and Amazonians is what constructs their identity. In the end of the novel, Nael takes one last stroll through the streets of Manaus and, once again, shares his insights:

[I came] back here on foot, in the rain, looking at the waste being dragged down the gutters, the lepers piled on top of one another, hunched up under the oitizeros. I looked, shocked and sad, at the city which was maiming itself as it grew, distancing itself from the port and the river, refusing to come to terms with its past [...]. I had left the little that remained of the trees and climbers to the fury of the sun and the rain. Looking after all this meant submitting myself to the past, a time that was dying inside me (Hatoum, 2000, pp. 264-265).
Manaus is "refusing to come to terms with its past" because this past has been dismissed, the "waste being dragged down the gutters" and "the lepers piled on top of one another" are the fragments that remained from this great enterprise called development. They remained, and they will always be there; there will never be a centre without its margins, every city that develops does it by "maiming itself" as it grows. It is, therefore, Western normativity that causes the past to "die inside" us as we go through the process of "developing". Ultimately, marginalised spaces and marginalised people both suffer the impositions of a normative hegemony; this has always happened and, in the Amazon, both the land and the population suffer the consequences of that: "we have never heard a TV evangelist exhort his congregation to stop the ecocide that ravages the planet". On the contrary, "many facilitate it by telethons for missionary work in places like the Amazon" (Gomides \& Vogel, 2000 , p. 153). And the reason why such "ecocides" are so frequently facilitated is that the implication of the Amazonian development goes much beyond financial matters; actually, everywhere Western "progress" is imposed, "[t]he transformation of the economy is accompanied by an even more accelerated transformation of the culture" (Gomides \& Vogel, 2000, p. 130).

This "more accelerated transformation" of Amazonian culture is undeniable, and the researchers consider it a "hopeful statistic [...] that 42 indigenous communities have not suffered contact with the West" yet, inasmuch as that allowed their culture to survive: "[t]hey are not yet clothed in orange overalls, not yet rocking to The Everly Brothers, and not yet titillated by the charms of Salomé". In their view, once Amazonian roads most often entail the development of nearby regions, "the brightest future for the survival of both indigenous communities and forests is distance from a highway (e.g., Northwestern corner of the country in the state of Amazonas)" (Gomides \& Vogel, 2000, p. 130).

For such "bright future" to become achievable, the cultural and financial "contributions" of the West must not be forced in the region. By now, some of Amazonian environment and population is still able to thrive, but the reason has not been consideration for the matters addressed by ecocriticism. Far from that, this lack of contact is not because foreign investors and Brazilian 
officials have embraced human rights. "Rather, it is because the Amazon is so vast that 'economic development' has not yet reached all the way into the interior. But it's coming fast" (Gomides \& Vogel, 2000, p. 136). In the words of Fabian (1983, p. 155), tradition and modernity are not opposed nor are they in conflict. All this is (bad) metaphorical talk. "What are opposed, in conflict, in fact, locked in antagonistic struggle, are not the same societies at different stages of development, but different societies facing each other at the same Time". The Amazon is not an Eden, it is not some mythological lost land that is there to make us "return to the past"; it is there right now, it exists as the rest of the world exists, and it is not less "meaningful" than developed regions, on the contrary. The chronological order of our development, from savage to civilised, is not a universal truth; the Amerindians are not what we were once, they do not (re)present our past and, as I honestly hope, we do not represent their future.

"Children from the neighbourhood were touching the convertible, marvelling at such a wonderful car; like a machine from another world. Stunted, rickety, but still seductive" (Hatoum, 2000, p. 157). Development, just like this convertible, just like Yaqub, has already shown us how beautiful its façade must be in order to keep functioning, hiding its "stunted, rickety" kernel. Interestingly enough, we have actually been deceived, we have actually been seduced like the children who touch the convertible. As it is shown in Hatoum's novel, the doors for the Amazon have indeed been opened, and with the impact of Western society on the lives of the Amazonians, they have both been decisive for their future. We can ponder upon the symbology of the car as a modern tool that, like the system, makes the driver a slave, always in need of money for its maintenance. This maintenance, and its high costs, are somehow seen as if they were worth it for the benefit of the illusion of conquest, of victory, power, superiority, progress, and, ultimately freedom.

Ironically, freedom is the first thing that the car takes from you since you will always need money in order to "deserve" it. Taking the metaphor even further, pondering upon the futility and status that are involved with the acquisition of a car might also take us to an interesting discussion. The character Quelé, the owner of the mentioned car, descending from Germans, represents very well many westernised values-not from a romantic perspective but a "realistic" one. Just like it happens in our modern society, his car is not a means of transportation but a tool for giving him status and power; Quelé himself admits that he "adapted the engine, the wheels, the windows and the bumpers from another car. From the shell he made a kind of stunted convertible" in order to manufacture "a monster intended to impress".

One can see how hybrid Quelé's car is: there is hybridity also in the relations of power the car seems to represent; the systems are converted, resignified, and such conversion is not dictated by tradition or history, but solely by hegemonic interests, by the need to come up with a profitable piece. Quelé is a smuggler whose interests are divided between money and prostitutes - caboclas or Amerindians whose stupefaction by the glamour of civilisation is enough for them to sell their bodies to those who can give them a glimpse of it. The prostitutes, who were only girls, left their clients in the middle of the room, ran to the car, and right there, on the sand, Quelé handed bottles of perfume, sweets, blouses and kisses. "He got fresh with the girls on the edge of the jungle, among the wet caladiums; they caressed him and begged him to take them for a spin in the Oldsmobile" (Hatoum, 2000, p. 155). Therefore, and just like it happens with the prostitutes, the system does with us like Quelé's car does with them; it seduces us to, afterwards, rape us, to take from us our freedom, our autonomy, our right to live and be.

\section{Slavery and deforestation: places privileged by nature but cursed by history}

As the narrator observes, in the future of the Amazon there is indeed no place for those marginalised Amazonians, like his mother and himself, and if their space and time belong to a future that does not acknowledge them, that makes Nael and Domingas - our contemporary slaves - spaceless and timeless in hegemonic terms. For Nael, then, the only thing left by development is the memory of an obliterated existence that he shall struggle to strengthen: "I only kept one of the letters [Yaqub had sent]. Not even that, in fact: the photograph in which he 
and my mother are together, laughing, in a canoe moored near the Bar da Margem. She's nearly adolescent, he almost a child" (Hatoum, 2000, p. 263).

When Domingas dies and Nael looks for something not to forget her, he does not do so because he is afraid their story together might disappear and then become meaningless, but because he is aware that, for the normative functioning of time and space, such history has never actually happened. Nael and Domingas are not part of hegemonic narratologies, no one really cares about their history, and that scares him quite a lot. His existence as a caboclo and his mother's as an Amerindian are, indeed, meaningless to the norm, and the issue is not the fear to forget one's past, but the fear of going unnoticed-in the end this is our greatest fear. "I cut my mother's face out, and kept that precious piece of paper, the only image of Domingas' face left. I can recognise her laughter on the few occasions she laughed, and imagine her large, full eyes, lost in some place in the past" (Hatoum, 2000, p. 263). Nael looks at a picture of his mother the same way you look at a picture of yours; knowing that it is not actually your mother in the paper, but a sole representation; we relate and ponder upon so much that the memories we have of her mix with our feelings and turns that photograph into an icon, into some part of her that might be tangible anew.

When one looks at the past through images or historic reports, he/she also tends to feel homesick of a time that does not exist any longer, of a time long gone. Even when one looks at a picture of oneself, the person in the photograph does not exist, the reality that surrounds him/ her becomes fictional, and you do not recognise yourself there because temporal and spatial constructions are not stable, and so there are not any identities. A picture of a war is not the war, a picture of our mother is not our mother, the face Nael cuts out is not Domingas', only his memories are real, only his recollection of the "few occasions she laughed", of her eyes "lost in some place in the past", are going to accompany him. That is the only thing that remains when a beloved person leaves us, but, if we are constituted by memories, this single thing can mean quite a lot.

Domingas and Nael represent the vast margin of the Amazon that has not been benefited by development but only institutionalised by it. And even though "inserted" in the future, the racism and prejudice these people suffer, and the maintenance of the colonial nature of their participation in the construction of Amazonian future unfortunately accompany their whole lives: "Zana trusted her [Domingas], but sometimes the neighbours' comments gave her a fright. These Indian girls cast a spell on the children: hadn't there been cases of strangulation, vampirism, poisoning, and even worse?" (Hatoum, 2000, p. 61) Such as our memory, which prohibits the past to be lost, lingers on, so does the suffering of Amazonian margin and, therefore, the dark side of the hegemonic pastoral dream is unveiled. The Indians and the migrants are still suffering the consequences of neo-liberalist lies, and the progress they have been expecting for so long never reaches them; every asset of development is previously directed to exact beneficiaries. For the others it tends to be always one step forward and two steps back. Perhaps Galeano was right when he said that, "places privileged by nature have also been cursed by history" (Galeano, 1997, p. 256).

Nael constructs the character Domingas, his mother, as the postcolonial subject who has to accept her condition as undeserving to be better assisted in the queer space and time where she is forced to be embedded in, and he observes his mother living her whole life for others, always helping, but never being helped. Hatoum is not asking the reader to think about how unfair it is for this to happen, he is just asking the reader not to turn a blind eye to the fact that this has happened and is still happening in the very climax of our contemporary development, progress, future, and etc: "Domingas was useful; and she only stopped being useful when she died, as I saw her die, almost as shrivelled-up as when she came to the house-for all I know, into the world" (Hatoum, 2000, p. 57).

So Halim kept living, even after he stopped being useful; Domingas would never be able to do that because her usefulness was part of her identity since she was born. Domingas, the "modern slave", different from Halim, did not have to deal with "distinct situations". If Halim died suffering the consequences of development, she was one of these consequences, and would never stop to wonder upon them, this kind of thing was not meant "for people like her". Perhaps the problem lies between "stop believing" and "stop being"; one can continue to 
live, being dragged by the flows of the water streams of the Negro, but one can also stop being what he/she is, losing his/her identity as he/she controversially tries to find it. Halim is the kind of person who the system needs to deceive, and Domingas is the kind that, no matter if she is deceived or not, she cannot do anything nor go anywhere in order to change her fate.

This is so for Domingas and Nael, if compared to Halim, Omar, and, in the end, Rânia, represent a pretty distinct level of attempts at resistance against the process of Amazonian insertion in the globalizing world map. Notwithstanding the resemblance of these characters' fears and anxieties, their ultimate shared lack of ability for "believing" that the future shall be a better one, the embodiment of their opposition before Amazonian development assumes distinct shapes. This is so for the masters, the family, even though emerging from the poor condition of underprivileged immigrants coming to work in Manaus, had the option of remaining "on the other side" or of joining Domingas and Nael. This option has never been given to the latter characters; they have always belonged to the margin and their entrance to the centre will always be very unlikely.

It takes nonetheless more than ideological eagerness to root your feet on the grounds of your past, to anchor on a safe harbour and say, "this is who/when/ where I am" and "this is who/when/where I am going to be". Omar, Halim, and Nael are incapable of allowing the system to integrate them; but Domingas, for better or for worse, becomes a pivotal tool for its ultimate functioning. Interestingly, this strong and mighty woman of deep feelings and severe attitudes dies "almost as shrivelledup as when she came to the house", according to Nael, "into the world". Humanising the figure of his mother, Nael shows the reader that, not only fragile, but as fragile as anyone else, his mother was forced to become strong; but her strength did not make her devoid of her humanity. At least when we are born and when we die, we can be sure we are equal to everyone else. Halim, Zana, Rânia, Domingas, Nael, Omar, and Yaqub, together with their specific relationship with the space that surrounds them, are a pessimist but realist picture of what we have been nourishing in contemporaneity. Their story gives us no answers, but leaves us with many questions.
Are we responsible for our reality? We have access to various cultural frameworks, and such cultural frameworks are determined by our ideological choices or beliefs-what happens with one's society, based on the histories of civilisation, is that everyone tends to follow a similar path when we think of this story narrated by Nael. What becomes clear is that it does not matter who you are and where you come from or want to go, in the end what really matters is maybe to define/identify/establish who, where, and when you think you are. The Amazon and its inhabitants are perhaps able to present us with distinct perspectives, and in an ideology-based society perspectives make all difference. Yaqub, the character that best represents everything we wish for in the modern world, is exactly the only one capable of eluding every other character, the one that deceives everybody and that, in the end, is no longer admired by anyone.

As Fabian has stated, "Neither political Space nor political Time are natural resources. They are ideologically construed instruments of power" (Fabian, 1983, p. 144). In his view, imperialist claims to the right of occupying "undeveloped" space for the common good of mankind "should be taken for what they really are: a monstrous lie perpetuated for the benefit of one part of humanity, for a few societies of that part, and, in the end, for one part of these societies, its dominant classes" (Fabian, 1983, p. 144). Hatoum's novel is depicted in a setting where it is impossible to believe in the western redemption as well as in the beneficial contact between neo-coloniser and neo-colonised, between the neoliberal time and space and the so-called savage ones. Domingas has suffered this contact with the coloniser, and Nael is the result, both with no prospects, no future. The single and normative manner for time to pass is no good for them; the chronology of capitalism exists for people like them to be disregarded and for hegemonic power to be reinforced. For those who live at the margin it is much better to remain devoid of developmentalist contributions.

To sustain their view on the difficulties faced by Ecocriticism in a period when hegemony turns a blind eye to most environmental issues, Gomides and Vogel draw an interesting parallel between slavery and Amazonian deforestation, showing that "the logic of slavery and that of deforestation are identical" (Gomides \& 
Vogel, 2007, p. 32). The arguments which were once used to justify slavery are akin to those applied today to justify the "development" of the region-they say that anyone who looks carefully at the dichotomy slavery/ environment are "struck by their similarity" (Gomides \& Vogel, 2007, p. 23). According to the authors, to find the common origin, one must recognize that slavery was an unethical expression of capitalism: money embodied in human flesh. "This same point can now be made about Amazonian deforestation. It continues because there is money in it, and the homology manifests itself in the complicity of today's consumers" (Gomides \& Vogel, 2007, p. 22).

One of the most obvious reasons for the criticism against the preservation of the Amazon is, therefore, the economic profitability of the region's "insertion" in the globalised world. If this is the case, then the basic premises for slavery and deforestation to take place are indeed the same: a vast area which is not being obliterated by the West is understood as a waste of resources, just like a native who is not enslaved would be. Likewise, when people benefited by environmental destruction and people benefited by slavery are both confronted with the possibility of pondering upon their actions, they simply prefer to ignore it. Any deep reflection about slavery is profoundly disturbing when one's ancestors were slaveholders. "Deforestation is similarly disturbing, especially when one's country is either the biggest deforester in the world or the biggest financier of that deforestation" (Gomides \& Vogel, 2007, p. 153-154).

However, the decision to deforest, like that of emancipation, cannot be argued on the basis of (mis) calculated costs and benefits. "Deforestation like slavery

\section{References}

Campbell, A. Reading Beyond a Universal Nature: Hopes for the Future of Ecocriticism. Ecocriticism Issue, 8(1), 1-21, 2010. Washington State University. Disponível em: <http://www. temple.edu/gradmag>. Acesso em: 15 mar. 2013.

Colás, S. Postmodernity in Latin America: The Argentine Paradigm. Durham: Duke UP, 1994. is a moral question and $[\ldots]$ is no more germane to the issue of land use than is the material welfare of a slave germane to the issue of human liberty" (Gomides \& Vogel, 2007, p. 28-29). The Amazon, like the slaves, like Domingas and Nael, is not there for one to make profit out of it; in the opinion of the authors we must learn to look at the land as we learned-some of us-to look at people, given their connection, as meaningful and not financially negotiable. If "the crux of the abolitionist literature is that slaves were not capital" (Gomides \& Vogel, 2007, p. 31), then the crux of ecocritical literature is that nature is not capital.

For how long are we going to "negotiate" with those (supposedly second nature) systems responsible for enslaving us? Profit is not a synonym for improvement, and the answer for solving social problems is not more opportunities for making money; we just have to look around for answers in places we tend to consider meaningless. One of this places, perhaps the most relevant for our moment, is the environment, which is not meaningful only when one is lost in reverie; environmental issues are materially relevant, and perhaps much more connected to our present and future than to our past-actually even those categories (past, present, future) can be easily problematised. Philips' argument that the environmental crisis has been the first step for us to look for environmental solutions is fairly plausible; after all, if nature had not been so much impacted by human carelessness, indeed one could never have realised how high the level of such impact has been. The fact that we had to be so detrimental to nature in order to understand this is indeed "considerably ironical", but that may explain our past actions. For our present and future, however, there is no excuse.

Escobar, A. Power and visibility: Development and the invention and management of the third world. Latin American Studies Program. Santa Cruz: University of California. October 2009. p. 428-442.

Fabian, J. Time and the Other: How Anthropology Makes Its Object. Columbia University Press, 1983. 
Galeano, E. Open Veins of Latin America. Trad. Cedric Belfrage. New York: Monthly Review Press, 1997.

Gomides, C.; Vogel, J. H. Amazonia in the Arts: Ecocriticism versus the Economics of Deforestation ${ }^{\mathrm{TM}}$. Latin American Studies Association. Pittsburgh, PA. 2007. 212 p.

Halberstam, J. Queer Temporality and Postmodern Geographies. In: A Queer Time and Place: Transgender Bodies, Subcultural Lives. New York: NYU Press, 2005. p. 1-21.

Hall, S. When was the Postcolonial? Thinking at the limit. In: Chambers, I.; Curti, L. The Postcolonial Question: Common Skies, Divided Horizons. London: Routledge, 1996.

Harvey, D. Responsibilities towards nature and human nature In: Spaces of hope. Edinburg UP, 2000.
Creative Destruction on the Land. In: The enigma of capital and the crisis of capitalism. Profile Books, 2010.

Hatoum, M. The Brothers. Trad. John Gledson. Bloomsbury Publishing, 2000.

Philips, D. Ecocriticism, Literary Theory, and the Truth of Ecology. New Literary History, The Johns Hopkins University Press, 30(3), 577-602, 1999. Disponível em: <http://www.jstor. org/stable/20057556>. Acesso em: 15 mar. 2013.

Rodríguez, J. M. Queer Sociality and Sexual Fantasies. Lecture at Center for Study of Sexual Cultures, Berkeley: University of California, 8, 331-348, February 2010. 